\title{
Decreased Permeability as a Mechanism of Resistance to Methyl Benzimidazol-2-yl Carbamate (MBC) in Sporobolomyces roseus
}

\author{
By A. NACHMIAS AND I. BARASH \\ Department of Botany, The Dr George S. Wise Center for Life Sciences, \\ Tel Aviv University, Tel Aviv, Israel
}

(Received 15 September 1975; revised 9 November 1975)

\begin{abstract}
SUMMARY
Mutants of Sporobolomyces roseus resistant to benzimidazole fungicides varied in their responses to 2-(thiazol-4-yl)benzimidazole (thiabendazole, TBZ), methyl I-(butylcarbamoyl)-benzimidazol-2-yl carbamate (benomyl) and methyl benzimidazol-2-yl carbamate (carbendazim, $\mathrm{MBC}$ ). Incorporation of $\left[{ }^{14} \mathrm{C}\right] \mathrm{MBC}$ into trichloroacetic acid extracts of the sensitive strain $\mathrm{S} 4$ increased during a $2 \mathrm{~h}$ incubation period, whereas incorporation into the resistant mutant M55 was unchanged. $\left.{ }^{14} \mathrm{C}\right] \mathrm{MBC}$ uptake by $\mathrm{S} 4$ cells was five times higher than that by M55. MBC was identified as the main radioactive compound inside the 54 cells and reached a level of $2.4 \mu \mathrm{g} / 100 \mathrm{mg}$ dry wt.

The compound MBC enters the cells of $S p$. roseus by a temperature-, energy-, $\mathrm{pH}$ - and concentration-dependent transport system which may be specific for compounds containing a benzimidazole nucleus. It is suggested that tolerance of M55 to MBC is due to decreased permeability of the cell to this compound.
\end{abstract}

\section{INTRODUCTION}

Systemic benzimidazole fungicides are effective against a wide range of plant pathogenic fungi (Evans, 197I) and provide disease control for agricultural and horticultural crops (Byrde, 1970; Erwin, 1973; Evans, 1971). However the usefulness of these fungicides has been reduced by the frequent appearance of resistant strains (Bollen, 197I; Erwin, I973; Schroeder \& Provvidenti, 1969). These strains show cross-resistance to all toxic benzimidazole derivatives (Erwin, 1973). The phenomenon precludes substitution among the various benzimidazole fungicides and endangers their further use in agriculture. Despite the isolation of numerous resistant strains during the past few years, information on their mode of resistance to the fungicides is scanty.

The two most prominent benzimidazole fungicides are benomyl and thiabendazole (TBZ). Benomyl breaks down rapidly in aqueous solutions to form MBC (Clemons \& Sisler, 1969), and the latter is probably the toxic material in the plant at sites removed from the points of application. MBC inhibits cytokinesis or mitosis by interference with spindle formation (Davidse, I973; Hammerschlag \& Sisler, 1972).

The epiphytic Sporobolomyces roseus is highly sensitive to benzimidazole fungicides and has been used for in vivo and in vitro bioassays (Gross \& Kenneth, 1973). Our study was undertaken to determine cellular processes which might explain the mode of resistance of $S p$. roseus to benzimidazole fungicides. 


\section{METHODS}

Organisms. Sporobolomyces roseus isolate 2224 was kindly provided by R. Kenneth of the Department of Plant Pathology, Hebrew University, Rehovot, Israel. A subculture made from a single cell of the original isolate sensitive to 0.I p.p.m. MBC was designated as S4. Strain S4 was used for mutagenesis with ethyl methanesulphonate (EMS) according to the procedure described by Lindegren et al. (1965). The treated organisms were centrifuged, resuspended in $2 \%$ sucrose and plated on selective media. Strains M24 and M34 were mutants selected on media containing TBZ and benomyl respectively. Strain M55 was a positive spontaneous mutant of $\$ 4$ selected on a medium containing benomyl.

Culture methods. The strains were maintained at $25^{\circ} \mathrm{C}$ on plates of YEG agar medium containing: yeast extract ( $5 \mathrm{~g}$ ), dextrose ( $\mathrm{I} 0 \mathrm{~g}$ ) and agar $(20 \mathrm{~g})$ in distilled water (I 1). Similar YEG agar media, containing 50 p.p.m. of either TBZ or benomyl, were used for selecting resistant mutants. The compounds were added in dimethylsulphoxide (final concentration less than $0 . \mathrm{I} \% \mathrm{v} / \mathrm{v}$ ). Toxicity studies were carried out in $250 \mathrm{ml}$ Erlenmeyer flasks containing $50 \mathrm{ml}$ of YEG liquid medium. Flasks were incubated on a reciprocal shaker at $28^{\circ} \mathrm{C}$.

For dry weight determinations, I $\mathrm{ml}$ suspensions were filtered through preweighed nitratecellulose membranes $(0.45 \mu \mathrm{m}$, Sartorius membrane filters). After washing with distilled water, the filters were dried for $4 \mathrm{~h}$ at $90{ }^{\circ} \mathrm{C}$, stored in a desiccator for an additional $24 \mathrm{~h}$ and reweighed. A linear relationship was established between absorbance at $540 \mathrm{~nm}$ and dry weight. Growth was expressed as the increase in dry weight during the exponential phase of growth, determined from the absorbance at $540 \mathrm{~nm}$, and from this the generation time was calculated.

Uptake of $\left[{ }^{14} \mathrm{C}\right] M B C$. The compound $\left[2-{ }^{14} \mathrm{C}\right] \mathrm{MBC}$, specific activity $\mathrm{II} \cdot 2 \mathrm{mCi} \mathrm{mmol}{ }^{-1}$, was used in uptake studies. Exponential phase cells from a YEG culture were washed in $0 . \mathrm{I}$ M-phosphate buffer, $\mathrm{pH} 7 \cdot 2$, by centrifuging at $5000 \mathrm{~g}$ for $10 \mathrm{~min}$. Samples of $7 \mathrm{mg}$ dry wt were transferred to $5 \mathrm{ml}$ of GNP medium containing $0.67 \%$ yeast nitrogen base (Difco), $0.3 \%$ Bacto-peptone (Difco) and $1 \%$ glucose, in $50 \mathrm{ml}$ Erlenmeyer flasks. Flasks were incubated on a reciprocal shaker for $20 \mathrm{~min}$ at $28^{\circ} \mathrm{C}$, and then $\left[2-^{14} \mathrm{C}\right] \mathrm{MBC}$ was added to give a final concentration of $0.2 \mu \mathrm{Ci} \mathrm{ml}^{-1}$. Incubation was continued for additional periods of time, until terminated by centrifuging at $10000 \mathrm{~g}$ for $10 \mathrm{~min}$.

The cells were washed six times in $0.2 \mathrm{M}$-phosphate buffer, $\mathrm{pH} 7.2(5 \mathrm{ml})$ containing $0.4 \mathrm{M}-\mathrm{KCl}, 0.01 \mathrm{M}-2$-mercaptoethanol, $0 . \mathrm{I} \mathrm{M}$-EDTA and 10 p.p.m. of non-labelled MBC. This washing procedure removed any weakly adsorbed radioactive compounds. The residue was extracted once with $5 \mathrm{ml}$ cold $5 \%(\mathrm{w} / \mathrm{v})$ trichloroacetic acid (TCA). Radioactivities were measured in all the above fractions, including the cell residue.

The radioactivity of each fraction was determined in a Packard Tricarb Model 2003 liquid scintillation counter by counting $0.1 \mathrm{ml}$ of the filtrate in $5 \mathrm{ml}$ of Bray's counting solution containing: 2,5-diphenyloxazole ( $8 \mathrm{~g})$, I,4-bis-[2-(4-methyl-5-phenyloxazolyl)]benzene $(0.6 \mathrm{~g})$, naphthalene ( $150 \mathrm{~g})$, methanol ( $100 \mathrm{ml}$ ), ethylene glycol $(20 \mathrm{ml})$ and $\mathrm{I}, 4-$ dioxane (to make I 1). All counts were corrected for background and quenching by the external standard method.

Thin-layer chromatography (t.l.c.) was employed to resolve radioactive components in the washings and TCA extract. Samples were spotted on $0.25 \mathrm{~mm}$ thick silica gel (G-254, Merck) and the t.l.c. plates were developed in benzene-acetone $(7: 1, \mathrm{v} / \mathrm{v})$ and ethyl acetate-methanol ( $10: \mathrm{I}, \mathrm{v} / \mathrm{v})$.

Chemicals. The $\left[2^{14} \mathrm{C}\right] \mathrm{MBC}$ was obtained from International Chemical and Nuclear 


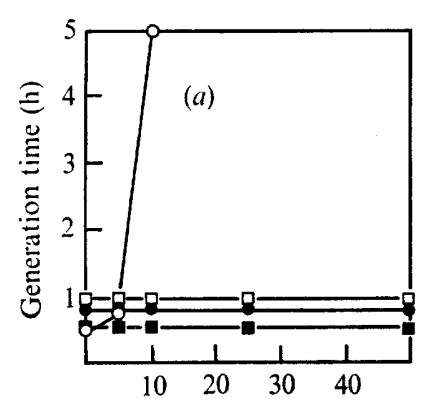

TBZ concentration $\left(\mu \mathrm{g} \mathrm{ml}^{-1}\right)$

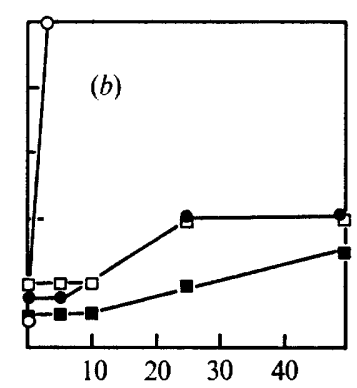

Benomyl concentration $\left(\mu \mathrm{g} \mathrm{ml}^{-1}\right)$

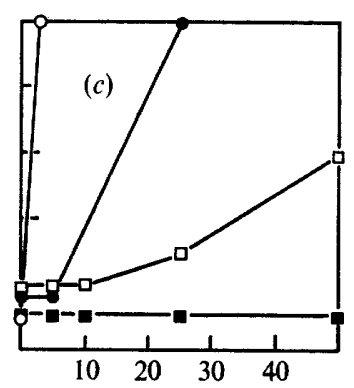

$\mathrm{MBC}$ concentration $(\mu \mathrm{g} \mathrm{ml}-)$

Fig. I. Growth rate of strains of $S p$. roseus at different concentrations of $(a) \mathrm{TBZ},(b)$ benomyl, (c) MBC. Organisms were grown in YEG agar medium as described in Methods. $\bigcirc$, s4; $\bigcirc$, M24; $\square$, M34; $\mathbf{\square}, \mathbf{M} 55$.

Corporation; recrystallized MBC, 2-amino benzimidazole and benomyl from Dupont; and TBZ from Merck. All chemicals or solvents were either analytical reagent grade or spectral grade.

\section{RESULTS AND DISCUSSION}

\section{Toxicity studies}

Dosage response plots for strains of $S p$. roseus that are resistant and sensitive to TBZ, benomyl and MBC are shown in Fig. I. The generation time of strain $\mathrm{s} 4$ increased from 0.5 to $5 \mathrm{~h}$ in the presence of either 3 p.p.m. benomyl or MBC whereas 10 p.p.m. TBZ were required to obtain similar inhibition. All the mutant strains exhibited a complete tolerance to TBZ up to a concentration of 50 p.p.m. (Fig. I $a$ ). In contrast, variations were detected in the sensitivity of the mutants to benomyl and MBC. Thus mutant M24 (selected on TBZcontaining medium) revealed only a slight resistance to $\mathrm{MBC}$ and a higher resistance to benomyl (Figs. I $b, c$ ); but mutant M55 (selected on benomyl-containing medium) was highly resistant to both benomyl and MBC. The data presented indicate that $\mathrm{MBC}$ and benomyl are more effective toxicants than TBZ to Sp. roseus. Strain M55 was used for further studies on the nature of resistance to $\mathrm{MBC}$.

\section{Uptake of $\left[{ }^{14} C\right] M B C$ by sensitive and resistant strains of Sp. roseus}

The incorporation of $\left[{ }^{14} \mathrm{C}\right] \mathrm{MBC}$ into TCA extracts of strains $\mathrm{S4}$ and $\mathrm{M} 55$ was measured after various incubation times. The amount of labelled compounds in $\mathrm{S} 4$ increased substantially during the first hour and reached saturation after approximately $3 \mathrm{~h}$ (Fig. 2). A significant amount of radioactivity was also detected in a TCA extract of M55, but this remained constant throughout the incubation period. After $2 \mathrm{~h}$ incubation, the radioactivity in $\mathrm{S} 4$ was five times higher than that in $\mathrm{M} 55$. At this time, 90 to $94 \%$ of the radioactivity remained in the medium, about $5 \%$ was removed from the cells by washing, and 5 and $1 \%$ respectively were detected in the TCA extracts of $\mathrm{S} 4$ and M55; the cell residue contained only traces of radioactivity. Under similar conditions Ustilago maydis removed approximately I \% MBC from the medium (Clemons \& Sisler, 1971), whereas spores of Pithomyces chartarum achieved almost complete removal of TBZ and other benzimidazole compounds (Stutzenberger \& Parle, 1972). These major differences in adsorption capacity between $S p$. roseus or $U$. maydis and $P$. chartarum could be attributed to variations in the adsorptive sites on the cell's surface. 


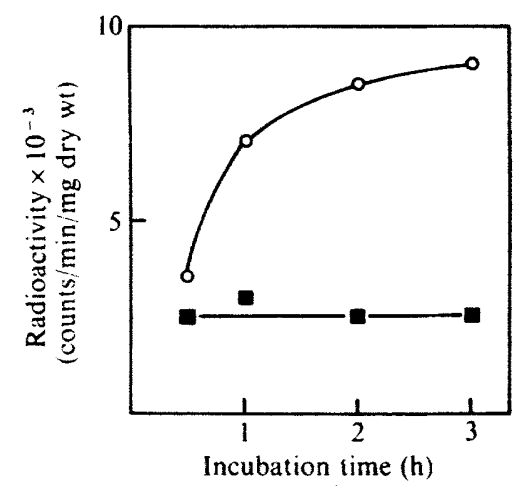

Fig. 2

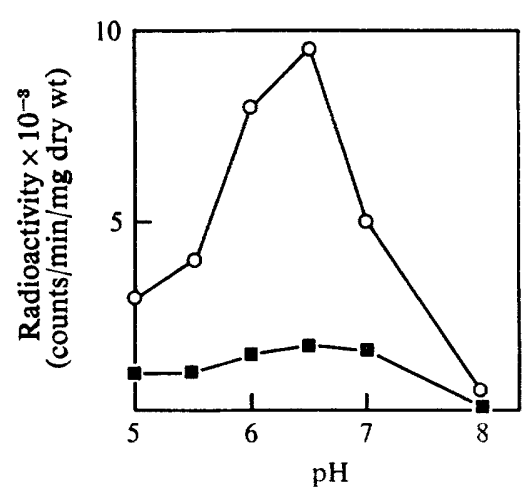

Fig. 3

Fig. 2. MBC uptake by strains $\$ 4$ and M55 as a function of time. Incubation was carried out in GNP medium, pH 6.5, containing 3.4 p.p.m. $\left[{ }^{14} \mathrm{C}\right] \mathrm{MBC}\left(0.2 \mu \mathrm{Ci} \mathrm{ml}{ }^{-1}\right)$ as described in Methods. $\bigcirc$, s4; a, M55.

Fig. 3. Effect of $\mathrm{pH}$ on uptake of $\left.{ }^{[4} \mathrm{C}\right] \mathrm{MBC}$. Cells of $\mathrm{s} 4$ and $\mathrm{M} 55$ were incubated for $2 \mathrm{~h}$ under the conditions described for Fig. 2. O, s4;, , M55.

The main radioactive component in all the different fractions was identified as $\mathrm{MBC}$ by t.1.c. The amount of MBC in the TCA extract of $\mathrm{s} 4$ was calculated to be $2.4 \mu \mathrm{g} / \mathrm{r} 00 \mathrm{mg}$ dry wt of cells. The observation that $\mathrm{MBC}$ is taken up in very small quantities by cells of $S p$. roseus is similar to that reported for $U$. maydis and Neurospora crassa (Clemons \& Sisler 1971). Nevertheless there were differences between the incorporation of $\left[{ }^{14} \mathrm{C}\right] \mathrm{MBC}$ into TCA extracts of sensitive and resistant strains (Fig. 2). The presence of radioactivity in the cold TCA extract could result from transport of $\left[{ }^{14} \mathrm{C}\right] \mathrm{MBC}$ into the soluble pool of the cells or by adsorption on to their outer surface. The following experiments were designed to distinguish between these two possibilities.

\section{$p H$ - and temperature-dependence of $\left[{ }^{14} \mathrm{C}\right] \mathrm{MBC}$ uptake}

Results in Fig. 3 show a distinct $\mathrm{pH}$ optimum for $\mathrm{MBC}$ uptake by strain s4. The maximum uptake by $\mathrm{S} 4$ at $\mathrm{pH} 6.5$ was more than five times higher than that by $\mathrm{M} 55$. The $\mathrm{p} K_{\mathrm{a}}$ of $\mathrm{MBC}$ is 4 and at $\mathrm{pH} 6.5$ it exists predominantly as an uncharged species (Aharonson $\&$ Kafkafi, 1975). Thus, the decrease in uptake at high $\mathrm{pH}$ could reflect the effect of $\mathrm{pH}$ on some cell components rather than on the ionic form of the substrate. The decrease in uptake at low $\mathrm{pH}$ could result from an effect on cell components as well as ionization of the molecule. It is interesting that the $\mathrm{pH}$ optimum for adsorption of benzimidazole compounds by $P$. chartarum conidia is 4.5 (Stutzenberger \& Parle, 1972).

The temperature-dependence of $\left[{ }^{14} \mathrm{C}\right] \mathrm{MBC}$ uptake is shown in Fig. 4. The high $Q_{10}$ (greater than 2 between $20^{\circ} \mathrm{C}$ and $30^{\circ} \mathrm{C}$ ) and activation energy of $606 \mathrm{~kJ} \mathrm{~mol}^{-1}$, as calculated by the Arrhenius equation, are characteristic of an active, carrier-mediated process. However, the latter results should be interpreted with care since, as shown below, MBC uptake is probably energy dependent. Thus, the results shown in Fig. 4 may reflect the temperature-dependence of energy production rather than the temperature-dependence of the transport system itself.

\section{Effect of extracellular $M B C$ concentration}

Figure 5 shows the rate of $\left[{ }^{14} \mathrm{C}\right] \mathrm{MBC}$ uptake as a function of $\mathrm{MBC}$ concentration. A saturation curve was obtained with a maximal uptake at approximately 2 p.p.m. (I $2 \mu \mathrm{M}$ ) MBC. 


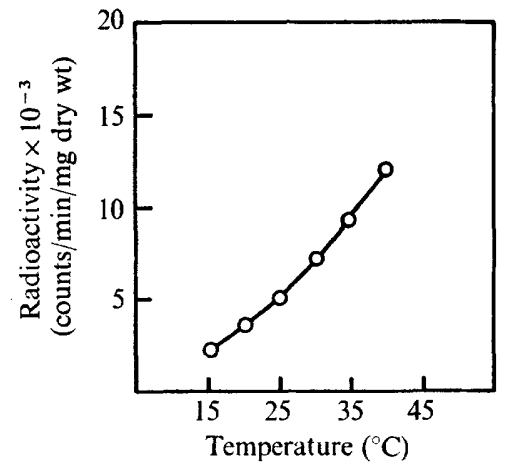

Fig. 4

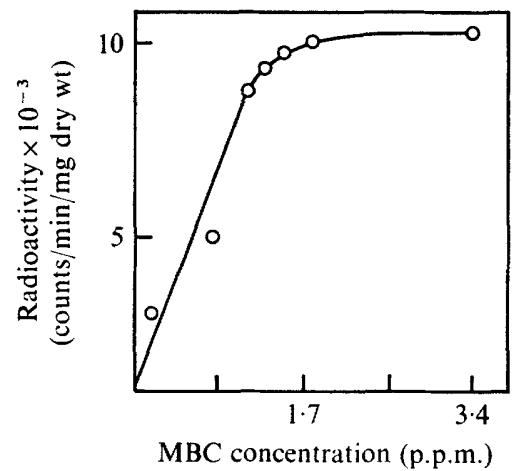

Fig. 5

Fig. 4. Effect of temperature on $\left[{ }^{14} \mathrm{C}\right] \mathrm{MBC}$ uptake by $\mathrm{s} 4$ cells. Incubation conditions were as for Fig. 2.

Fig. 5. Effect of $\mathrm{MBC}$ concentration on $\left[{ }^{14} \mathrm{C}\right] \mathrm{MBC}$ uptake. Incubation was carried out under the conditions described for Fig. 2. Uptake was terminated after $2 \mathrm{~h}$ incubation period.

Table I. Effect of various metabolic inhibitors on $M B C$ uptake

Organisms were pre-incubated aerobically for $15 \mathrm{~min}$ in GNP medium containing $10^{-3} \mathrm{M}$-inhibitor, before $\left[{ }^{14} \mathrm{C}\right] \mathrm{MBC}$ was added. MBC uptake was measured for $2 \mathrm{~h}$ under conditions described in Methods.

\begin{tabular}{clc} 
Strain & \multicolumn{1}{c}{ Addition } & $\begin{array}{c}\text { Relative } \\
\text { uptake rate } \\
\text { (\% of control) }\end{array}$ \\
S4 & None (control) & 100 \\
S4 & Sodium azide & 20 \\
S4 & 2,4-Dinitrophenol & I8 \\
S4 & p-Chlorophenol & I8 \\
S4 & Sodium cyanide & 13 \\
M55 & None (control) & 100 \\
M55 & Sodium azide & 75
\end{tabular}

Table 2. Effect of benzimidazole derivatives and other compounds on $M B C$ uptake by strain $\mathrm{s} 4$

Organisms were incubated under the conditions described in Table $\mathbf{I}$. The compounds tested were added simultaneously with the labelled MBC.

$\begin{array}{lcc}\text { Addition } & \begin{array}{c}\text { Concen- } \\ \text { tration } \\ \text { (p.p.m.) }\end{array} & \begin{array}{c}\text { Relative } \\ \text { uptake rate } \\ \text { (\% of control) } \\ \text { None (control) }\end{array} \\ \text { TBZ } & - & 100 \\ \text { TBZ } & 5 & 68 \\ \text { 2-Aminobenzimidazole } & 25 & 45 \\ \text { Histidine } & 25 & 38 \\ \text { Guanine } & 10 & 100 \\ \text { Yeast extract } & 10 & 100 \\ & 0.3 \% & 14\end{array}$




\section{Energy-dependence and specificity of $M B C$ uptake}

The uptake of MBC was inhibited by $80 \%$ or more after a brief pre-incubation of $\mathrm{s} 4$ cells with known respiratory inhibitors (Table $\mathrm{I}$ ). These results suggest that MBC transport is energy dependent. The uptake inhibition of $25 \%$ observed for strain M55 in the presence of sodium azide (Table I) suggests that although the permeability of resistant cells to MBC was significantly inhibited (Fig. 2), it was not entirely excluded. However, the accumulation of the toxicant in the tolerant strain is not sufficient to show a fungistatic action.

The specificity of the MBC transport system was investigated by determining the effect of structurally-related compounds on $\left[{ }^{14} \mathrm{C}\right] \mathrm{MBC}$ uptake (Table 2). Derivatives of benzimidazole such as TBZ or 2-amino-benzimidazole acted as effective inhibitors of MBC transport. Guanine and histidine, which contain a purine and an imidazole nucleus respectively, were ineffective. The highest inhibition, caused by yeast extract, is presumably due to the presence of benzimidazoles or structurally-related compounds which compete with $\mathrm{MBC}$ for the transport system.

The results suggest that the incorporation of $\left[{ }^{14} \mathrm{C}\right] \mathrm{MBC}$ into the TCA extract is mediated by an active transport system. Such a system may be specific for compounds containing a benzimidazole nucleus and is dependent on energy, $\mathrm{pH}$, temperature and $\mathrm{MBC}$ concentration. A part of the $\left[{ }^{14} \mathrm{C}\right] \mathrm{MBC}$ in the TCA extract could result from adsorption of the fungicide on to the cell surface, as reported for other fungi (Clemons \& Sisler, I97I; Stutzenberger \& Parle, 1972). The observed differences in tolerance and $\mathrm{MBC}$ uptake between strains S4 and M55 (Figs. I $c$ and 2) can be attributed to an impairment of the MBC uptake system in the latter strain. If a similar resistance mechanism existed in other tolerant strains, cross-resistance (Figs. I $a, b, c$ ) could depend on decreased permeability to benzimidazole fungicides.

\section{REFERENCES}

Aharonson, N. \& Kafkafi, U. (1975). Adsorption of benzimidazole fungicides on montmorillonite and kaolinite clay surface. Journal of Agricultural and Food Chemistry 23, 434-437.

Bollen, G. J. (1971). Resistance to benomyl in strains of Penicillium sp. Netherlands Journal of Plant Pathology 77, 187-192.

Byrde, R. J. W. (1970). The new systemic fungicides and their potential use in the tropics. Tropical Science 12, $105-108$.

Clemons, G. P. \& Sisler, H. D. (1969). Formation of a fungitoxic derivative from benlate. Phytopathology 59, $705-708$.

Clemons, G. P. \& Sisler, H. D. (I971). Localization of the site of action of a fungitoxic benomyl derivative. Pesticide Biochemistry and Physiology r, 32-43.

DAVIDSE, L. C. (I973). Antimitotic activity of methyl benzimidazole-2-yl carbamate (MBC) in Aspergillus nidulans. Pesticide Biochemistry and Physiology 3, 31 7-329.

ERWIN, D. C. (1973). Systemic fungicides: disease control, translocation and mode of action. Annual Review of Phytopathology 11, 389-422.

Evans, E. (1971). Systemic fungicides in practice. Pesticide Science 2, 192-196.

Gross, Y. \& KenNeth, R. (1973). The fate of benomyl and thiabendazole in seed and soil treated plants. Annals of Applied Biology 73, 307-318.

Hammerschlag, R. S. \& SiSler, H. D. (I972). Differential action of benomyl and methyl-2-benzimidazole carbamate (MBC) in Saccharomyces pastorianus. Pesticide Biochemistry and Physiolcgy 2, 126-131.

Lindegren, G., Hwang, Y. L., Oshima, Y. G. \& Lindegren, C. L. (I965). Genetical mutants induced by ethyl methanesulphonate in Saccharomyces. Canadian Journal of Genetics and Cytology 7, 49I-499.

Schroeder, W. T. \& Provvidenti, R. (1969). Resistance to benomyl in powdery mildew of cucurbits. Plant Disease Reporter 53, 27I-273.

Stutzenberger, F. J. \& Parle, J. N. (1972). Binding of benzimidazole compounds to conidia of Pithomyces chartarum. Journal of General Microbiology 73, 85-94. 